\title{
National Security, Private Actors, and Political Risk: Judicial and Non-Judicial Responses
}

\section{An Introduction}

\author{
Stephan W Schill | ORCID: 0000-0002-1458-0814 \\ University of Amsterdam, Amsterdam, The Netherlands \\ s.w.b.schill@uva.nl \\ Geraldo Vidigal | ORCID: 0000-0001-6319-7750 \\ University of Amsterdam, Amsterdam, The Netherlands \\ g.vidigal@uva.nl
}

Discussions of the relationship between national security and international economic law often focus on the dilemma between the interests of States to reap advantages from inter-State cooperation and increased globalization, on the one hand, and their desire to retain the ability to make decisions independently on matters of vital interest, on the other hand. The focus on inter-State relations, however, conceals the fact that international economic law takes place on more than one plane. Besides constraining States' conduct at the inter-State level, international economic law also establishes an environment for (mostly) private economic actors that shields their activities against arbitrary, discriminatory, and other unfair conduct by States and requires States to create and enforce predictable rules for the unfolding of private economic activity. International economic law therefore generates effects not only for the relations between States, but also for the relations between States and private economic actors and, indirectly, for relationships between private actors, as it impacts the decision-making and strategies those actors adopt in increasingly globalized markets.

As a matter of inter-State relations, the legalization and judicialization of international economic relations - not only during the 2oth century, but already since the 'first wave of globalization'1 that started in the late 19th century - have

1 Kevin HO Rourke and Jeffrey G Williamson, Globalization and History: The Evolution of a Nineteenth-Century Atlantic Economy (MIT Press 1999); Thomas Piketty, Capital in the Twenty First Century (Harvard UP 2014) 37. 
always safeguarded policy space for State measures taken on grounds of national security. Thus, when States agreed at the 1899 Hague Convention on the Pacific Settlement of International Disputes to complement diplomacy with binding dispute settlement under international law, replacing the use of force as a means of pursuing foreign policy interests and settling international conflicts, they already made sure that certain issues would be exempted from international adjudication. While Article 16 of the 1899 Hague Convention recognized that 'arbitration is ... the most effective, and at the same time the most equitable, means of settling disputes which diplomacy has failed to settle', it limited that insight to 'questions of a legal nature.'2 Political questions, which were understood as those relating to the vital interests or essential security of States, were assumed to be excluded by this formulation - and could easily be framed to cover certain matters of inter-State commerce. ${ }^{3}$

As international economic agreements during the 2oth century increasingly featured compulsory adjudication, the position that measures taken in the name of national security should be exempted entirely from all accountability under international law became increasingly untenable, not only as a matter of inter-State relations, but also in light of international economic law's objective of providing security to private economic actors engaged in transborder trade and investment. For private actors, the invocation of national security by States as a justification for certain measures, and the possibility that such measures cause economic harm, qualifies as 'political risk.' This risk increases proportionately with the degree of uncertainty an open-textured concept like national or essential security brings, as well as with the inclination of States to rely on it to justify measures that restrict trade and investment. It is one thing, also from a risk management perspective of private actors, to see national security invoked when genuine threats to a State's existence, its territorial integrity, or political independence are at stake, but it is quite another when national security is used to advance non-security objectives or to justify measures that, although legitimately related to a security objective, impose restrictions on commercial actors that would, under any other objective, be judged excessive and unnecessary.

In light of this prospect, the invocation of national security in the field of international economic relations became the subject of, first, specifically worded

2 Convention for the Pacific Settlement of International Disputes (signed 29 July 1899, entered into force 4 September 1900) 187 CTS 410, art 16.

3 On the historic distinction between political and legal disputes that are also reflected in art 16 of the 1899 Hague Convention, see Hersch Lauterpacht, Function of Law in the International Community (Clarendon 1933) 27-29, 139-44. 
treaty provisions and, second, international adjudication. Thus, numerous international trade and investment agreements concluded since the end of World War II contain provisions, such as Article XXI of the General Agreement on Tariffs and Trade, ${ }^{4}$ dealing with 'essential security interests' or 'national security,'5 that allow States to derogate from commitments made in respect of foreign traders and investors and that set up conditions for such derogation. When seized with the issue, international courts and tribunals, including the International Court of Justice (ICJ), World Trade Organization (WTO) panels, and investment treaty tribunals, have accepted jurisdiction in disputes under economic agreements to determine whether questions of national security were at stake and justified the taking of measures that deviated from the State's international legal commitments in question. ${ }^{6}$

For non-State economic actors, the review exercised by international courts and tribunals is one way of managing the political risk connected to States' reliance on national security. The rather robust approach of international courts and tribunals to the issue of national security notwithstanding, juridification and judicialization of national security as means of limiting political risk are neither uncontested, nor necessarily complete in covering all areas of transborder commerce. Thus, more recently, some States have started including fully self-judging security exceptions into their trade and investment agreements, seeking to prevent any international scrutiny, including in respect of measures that affect existing investments and established trade relations.

4 General Agreement on Tariffs and Trade, Annex IA the Agreement Establishing the World Trade Organization (adopted 15 April 1994, entered into force 1 January 1995) 1867 UNTS 154.

5 For an overview of different models of security exceptions in trade and investment agreements, see United Nations Conference on Trade and Development (UNCTAD), The Protection of National Security in IIAs (2008) UNCTAD/DIAE/IA/2008/5. See also Sebastián Mantilla Blanco and Alexander Pehl, National Security Exceptions in International Trade and Investment Agreements - Justiciability and Standards of Review (Springer 2020).

6 For references to the jurisprudence, see Geraldo Vidigal and Stephan W Schill, 'International Economic Law and the Securitization of Policy Objectives: Risks of a Schmittean Exception' (2021) 48(2) Legal Issues of Economic Integration 109, 111, fn 8-10. International courts and tribunals recognized, however, that the degree of scrutiny they could exercise also depended on the wording of security exceptions. Clauses featuring self-judging elements, for example, were recognized to grant greater discretion to invoking States and to limit the standard of review exercised by an international adjudicatory body from full scrutiny to compliance with good faith. See WTO, Russia - Traffic in Transit, Report of the Panel (26 April 2019) WT/512/R, paras 7.102 ff; Saudi Arabia - IP Rights, Report of the Panel (16 June 2020) WT/567/R, para 7.231. See also Certain Questions of Mutual Assistance in Criminal Matters (Djiboutiv France) (Judgment) [2008] ICJ Rep 177, 229. See further Stephan W Schill and Robyn Briese, "If the States Considers": Self-Judging Clauses in International Dispute Settlement' (2009) 13 Max Planck Yearbook of United Nations Law 61. 
For example, under the 2010 United States-Korea Free Trade Agreement, as well as under the Comprehensive Economic Cooperation Agreement between India and Singapore, resort to the Agreements' security exception is intended to be exempt from international scrutiny. ${ }^{7}$ Similarly, there are numerous areas of transborder commerce that are still largely beyond the reach of both treaty provisions limiting reliance on national security and possibilities for recourse to international adjudication. For example, the establishment of foreign investments, as well as the participation in public procurement, are areas that are often not even covered by any commitment of States under international law or are excluded from international adjudication to which private actors have access. This leaves private actors largely unprotected and at the whim of government authorities when deciding on market access and participation in procurement proceedings, subject only to the limits national law may impose.

The political risk implications of States' reliance on national security under international economic agreements was one of the recurring themes discussed at the conference we organized in Amsterdam on 14 and 15 November 2019 on International Economic Law and Security Interests. ${ }^{8}$ The three articles that form part of this Special Issue on 'National Security, Private Actors, and Political Risk' were written by participants of that conference. They focus on how the potential for invocation by States of national security to deny foreigners economic opportunities impacts the relationship between State autonomy and international economic law and the choices of economic actors when no, or only unreliable, protection of their economic interests is provided, and what mechanisms exist or can be devised to minimize the political risk implications of measures taken in the name of national security.

In the first article, Momchil Milanov focuses on international adjudication as the most traditional form of addressing abuses in a State's reliance on national

7 See Free Trade Agreement Between the United States and the Republic of Korea (concluded 3 December 2010, entered into force 15 March 2012) art 23.2(b), fn 2 (providing that 'if a Party invokes [the security exception] in an arbitral proceeding ... the tribunal or panel hearing the matter shall find that the exception applies') <https://ustr.gov/trade-agreements/free-trade -agreements/korus-fta/final-text>; India-Singapore Comprehensive Economic Cooperation Agreement (signed 29 June 2005, entered into force 1 August 2005) art 6.12(4) <www .enterprisesg.gov.sg/-/media/esg/files/non-financial-assistance/for-companies/free-trade -agreements/CECA_India/Legal_Text/Chapter6_Investment> both accessed 22 June 2021.

8 For another of the main themes of the conference, namely the broadening of the notion of national security and its use by States to justify a variety of different, partly economic, partly non-economic concerns, see the contributions in Geraldo Vidigal and Stephan W Schill, 'Special Issue: International Economic Law and the Evolving Notion of Security' (2021) 48(2) Legal Issues of Economic Integration 109-221. 
security in order to justify deviating from existing treaty commitments. ${ }^{9}$ Milanov not only analyzes in depth the case law of the ICJ, WTO panels, and investment treaty tribunals on security exceptions, he views the resulting jurisprudence as part of the intellectual heritage of Hersch Lauterpacht, which sees international courts and tribunals as guardians protecting the international legal order against unilateral State action that threatens international law's objective of ensuring international peace. Indeed, for those engaged in international commerce, unilateral State action constitutes an important part of political risk that can threaten the prosperity promised by globalization.

Judicialization and juridification are also the instruments of choice for Cheng Bian for minimizing political risk in the context of investment screening mechanisms. ${ }^{10}$ Such mechanisms are receiving increased attention again, not least since the European Union passed a regulation dealing with investment screening in 2019 in order to react more effectively against, amongst others, takeovers of strategically important companies by foreign investors, such as Chinese State-owned companies. ${ }^{11}$ Bian points out that political risk arises not only from the very existence of possibilities for investment screening, but also from the domestic legal framework under which these mechanisms are set up. Comparing the screening mechanisms that exist in Germany and China, he identifies three specific problems foreign investors face with these mechanisms: unpredictability, procedural uncertainty, and the lack of transparency. To remedy these concerns, and reduce political risk in respect of market access for foreign investors, Bian suggests regulating investment screening within international agreements that feature dispute settlement mechanisms.

Yet, judicialization and juridification are not the only responses that are possible to address political risk connected to national security. Thinking outside the box of the typical responses given by lawyers to virtually any societal problem - that is, more law and better and more efficient adjudication - is needed and fruitful, particularly in a field, such as national security, where States appear increasingly hesitant to assume more and more effective legal commitments and submitting to more intensive adjudicatory control. As Teoman Hagemeyer and Jens Hillebrand Pohl explore in respect of foreign investment

$9 \quad$ See Momchil Milanov, 'A Lauterpachtian Affair: Security Exceptions as "Self-Judging Obligations" in the Case Law of the International Court of Justice and Beyond' (2021) 22 JWIT 509-6o.

10 Cheng Bian, 'Foreign Direct Investment Screening and National Security: Reducing Regulatory Hurdles to Investors Through Induced Reciprocity' (2021) 22 JWIT 561-95.

11 Regulation (EU) 2019/452 of the European Parliament and of the Council of March 2019 Establishing a Framework for Screening of Foreign Direct Investments into the Union (21 March 2019) OJ L 79/I 1. 
screening, market mechanisms using specific insurance instruments could be devised to minimize political risk. ${ }^{12}$ Such insurance would allow States to maintain full control over their national security interests and shield their economies, on an individual basis, against incoming foreign investors, while ensuring that the negative financial impact on involved commercial actors is alleviated through the payment of the insurance sum.

The need for and legitimacy of protecting national security is beyond doubt. It is accepted practice the world over for States to take action to protect national security and, in doing so, to interfere with the interests of foreign sovereigns and their nationals. At the same time, from the perspective of economic actors, State action to protect national security - in particular when it is unchecked and lacking in predictability - can constitute an unacceptable political risk for their trade and investment ventures and translate into concrete financial harm, stifling interconnected economic activity. Apart from limiting abuses of the invocation of national security, it is principally these financial consequences that international economic law can sensibly address, thereby easing, perhaps even reconciling, the tensions between national security concerns and globalization.

12 Teoman M Hagemeyer and Jens Hillebrand Pohl, 'Managing the Risk of Self-Judging Security Exceptions Through Insurance: How Recent Mergers and Acquisitions Practice Copes with Investment Screening' (2021) 22 JWIT 596-625. 